\title{
AKHLAK TERPUJI DALAM PENDIDIKAN AGAMA ISLAM SEBAGAI LANDASAN DALAM TANTANGAN MULTIKULTURAL
}

\author{
Nama : Firgiansah Tungkagi \\ Email : Tungkagi4321@gmail.com
}

\section{A. Pendahuluan}

Indonesia adalah negara yang multikultural, semua itu dapat terlihat dari budayanya yang sangat banyak, suku dan agama yang hidup berdampingan dalam satu lingkungan yang baik. Akan tetapi terkadang dalam hal bersosial dalam seharihari terkadang terdapat beberapa masalah, terurama masalah agama yang mungkin kurang sedap dalam pandangan mata dan pendengaran telinga. Oleh karena penekanan terhadap nilai multikultural itu sangatlah penting dimana melalui pemahaman yang baik tentang toleransi dan saling menghargai antar sesama dapat terwujud melalui penekanan nilai multikultural tersebut. Makanya perlu adanya pengembangan dalam pembelajaran tentang nilai multikultural sebagai jawaban atas tantangan beberapa masalah yang dihadapi sekarang dan di kemudian hari. Hal ini dapat terwujud dengan mengambangkan nilai multikulrural dalam pembelajaran dengan cara memasukan nilai atau unsur multikultural itu sendiri dalam pendidikan ${ }^{1}$.

Di sekolah-sekolah sebenarnya sudah banyak yang menerapkan nilai multikultural terbukti dengan keberhasilan hidup rukunnya beberapa suku dan agama yang hidup dalam satu lingkungan. Namun dalam hal ini masih ada beberapa hal yang mengakibatkan terjadinya pergeseran nilai multikultural itu dalam kehidupan antar umat $^{2}$, untuk itu perlu adannya beberapa pengembangan tentang hal ini karna pemahaman terhadap nilai multikultural ini sangatlah penting mengingat negara kita ini yang terdiri dari banyak sekali suku, bangsa dan agama. Agama islam sendiri adalah agama yang sangat multikultural, banyak sekali ayat al-qur'an yang menjelaskan tentang toleransi antar umat dalam hal mu'amalah. Dalam hal ini sangat

\footnotetext{
${ }^{1}$ Muhammad Anas Ma`arif, 'Pendidikan Islam Dan Tantangan Modernitas', Nidhomul Haq: Jurnal Manajemen Pendidikan Islam 1, no. 2 (26 March 2016): 47-58.

${ }^{2}$ Muhammad Anas Ma`arif, 'Internalisasi Nilai Multikulutural Dalam Mengembangkan Sikap Toleransi ( Studi Di Di Pesantren Mahasiswa Universitas Islam Malang)', Nazhruna: Jurnal Pendidikan Islam 2, no. 1 (24 March 2019), https://doi.org/10.31538/nzh.v2i1.179.
} 
sejalan dengan semboyan kita di negara kita tercinta ini yang yaitu Bhineka Tunggal Ika yang artinya berbeda-beda tetapi tetap satu. ${ }^{3}$

Pada prinsipnya pendidikan multikultural adalah pendidkan yang menghargai perbedaan. Pendidikan multikultural senantiasa membuat konsep dan proses melalui yaitu kebudayaan yang bisa melakukan hasil yang dapat dilihat dari prakteknya dalam kehidupan,. ${ }^{4}$

Dalam hal ini agama Islam mengajarkan nilai tersebut sebab agama Islam sangat menjunjung nilai tolransi antar sessama dan menghargai perbedaan. Maka dari itu dalam pendidikan agama Islam sangat perlu pengajaran terhadap multikultural tentunya dalam penbelajaran disekolah. Ini menjadi perhatian bersama khususnya bagu guru agama atau PAI disekolah dimana guru PAI harus paham dan harus bisa menjelaskan secara baik nilai multikultural dalam pembelajan sehingga nantinya pemahaman siswa terhadap nilai-nilai multikultural akan maksimal dan terarah.

Mengingat tentang pentingnya hal ini maka dalam ini akan ditulis tentang beberapa tantangan dalam multikultural yang harus di capai agar sebab maksimalnya nilai multikultural di indonesia.

\section{B. Pembahasan}

\section{Pengertian multikultural}

Akar kata multikulturalisme yaitu kebudayaan. ${ }^{5}$ Multikultural dapat dipahami sebagai pengakuan penerimaan suatu perbedaan seperti Agama, Ras, suku, dan perberdaan yang terjadi dalam lingkungan sekitar dalam hal ini tidak bertentangan dengan norma yang berlaku. Multikultural tidak hanya bagi kewarganegaran tetapi juga dalam pendidikan. Multikultural memiliki arti yang sangat luas, terdiri dari dua kata yaitu multi yang artinya "plural" dan kultural yaitu "suatu penjelasan tentang budaya"6. Jadi multikultural adalah suatu paham yang menjelaskan tentang keragaman budaya dan pandangan terhadap budaya tersebut.

Multikulturalisme sebagai sebuah paham yang menekankan pada kesededarajatan dan ksesetaraan budaya-budaya lokal tanpa mengabaikan hak-hak dan eksistensi budaya yang lain penting kita pahami bersama dalam kehidupan

${ }^{3}$ Rohani, 'Wawasan Multikultural Dalam Pendidikan Agama Islam', JUrnal Al-Qalam XI, no. 63 (2000): 63 .

${ }^{4}$ Choirul Mahfud, Pendidikan Multikultural, VI (Yogyakarta: Pustaka Pelajar, 2013), xiii.

5 Parsudi Suparlan, 'Menuju Masyarakat Indonesia Yang Multikultural', Antropologi Indonesia 69 (2002): 100 .

${ }^{6}$ Muhammad Yahya, 'Pendidikan Islam Pluralis Dan Multikultural', Lentera Pendidikan 13, no. 2 (2010): 2, https://doi.org/10.1016/0165-7836(95)00430-0. 
masyarakat yang multikultural seperti Indonesia. Jika tidak, dalam masyarakat kita kemungkinan besar akan selalu terjadi konflik akibat ketidak saling pngertian da pemahaman reaslistis multikultural tersebut. ${ }^{7}$

Makanya tugas sebagai pendidik adalah mampu menjelaskan paham dan nilainilai multukultural secara baik dan benar agar tercapainya tujuan pendidikan multikultural khusunya dalam pendidikan agama islam. Ada beberapa yang perlu kita tanamkan dan kita biasakan kepada peserta didik dalam hal menyikapi perbedaan dilingkungan mereka yaitu dengan akhlak yang baik dan benar sesuai dengan ajaran islam agar nantinya peserta didik dalam bertindak dan menyikapinya tidak akan salah dan merujuk kepada hal-hal yang tidak dinginkan sehingga nanti sesaui dengan tujuan pendidikan agama dan pendidikan multukultural. Beberapa hal tersebut sangat perlu di tanamkan pada peserta didik dalam hal pembelajaran agama Islam. ${ }^{8}$ Berikut ini adalah beberapa Poin penting yang dapat kita ajarkan dan dibiasakan serta di tekankan dalam pembelajaran yaitu.

\section{Toleransi}

Toleransi berasal dari bahasa latin tolerare yang artinya bertahan atau memikul. Toleransi atau toleran adalah saling membantu atau memikul walaupun hal itu terkadang tidak kita sukai atau pun disukai tetapi harus kita kerjakan bersama dalam hal ini saling membantu sesama untuk mencapai tujuan kebaikan. Sifat toleransi ini sangatlah penting dan harus ditanamkan kepada peserta didik sejak dini sehinnga nantinya dia mampu menyesuaikan diri ketika sedang ada dalam lingkungan yang berbasis multi culture. ${ }^{9}$

Di indonesia tentunya setiap daerah memiliki kultur daerah yang berbeda-beda sebab seperti yang telah dijelasakan sebelumnya bahwa indonesia sangatlah beragam, Indonesia memilki lebih dari 300 kelompok dan 1.340 suku terdapat di indonesia hal tersebut juga sering dikatakan oleh bapak Presiden Indonesia Jokowi di beberapa acara besar seperti yang disampaikannya di acara Harlah Muslimat NU yang ke-73 di Gelora Bung Karno, Senayan Jakarta.

\footnotetext{
${ }^{7}$ Mahfud, Pendidikan Multikultural, xix.

${ }^{8}$ Mahfud, 34.

${ }^{9}$ Mustopa, 'Akhlak Mulia Dalam Pandangan Masyarakat', Nadwa 8, no. 2 (2014): 269.
} 
Hal ini tentunya menjadi perhatian bersama khusunya dibidang pendidikan sebab pendidikan haruslah menselaraskan dan mensingkronkan antara pendidikan dan budaya sehingga menjadi satu konsep pemahaman yang baik yang nantinya akan ditanamkan kepada peserta didik yang nantinya hal tersebut akan menjadi acuan mereka ketika mereka berada di lingkungan yang multi cultur. Ini adalah tantangan bagi kita sebagai seorang pendidik untuk bagaimana caranya agar hal tersebut mampu terwujud dilingkungan masyarakat dan peserta didik khususnya sebagai guru pendidikan Agama Islam. Dalam Islam nilai-nilai saling menghargai dan memahami itu sangatlah di ajurkan oleh karena itu Islam sangat menjunjung tinggi nilai toleransi antar sesama karna perbedaan adalah rahmat dari Allah SWT. Hal ini sejalan dengan simbol negara Indonesia yaitu Bhineka Tunggal Ika yamg artinya berbeda-beda tetapi tetap satu ${ }^{10}$.

Melihat hal tersebut maka sifat seperti toleransi dan saling memahami antar sesama sangatlah penting dan menjadi tantangan bagi pendidik untuk bisa mewujudkan hal ini, salah-satu upaya yang dapat dicapai adalah dengan menanamkan sifat toleransi kepada peserta didik dengan memasukkan nilai-nilai yang bersifat toleransi dalam pembelajaran dan mensingkronkan dengan budaya mereka yang tentunya nanti Agama menjadi filter mereka dalam menyikapi budaya mereka supaya nantinya ketika mereka berbudaya mereka akan bebudaya berdasarkan landasan agama sehingga nantinya akan menfilter kekeliruan dalam berbudaya. Ketika hal ini mampu terwujud dalam pembelajaran dan peserta didik mampu mengaplikasikan dalam kehidupan mereka maka ini hal ini berpotensi bisa mewujudkan masyarakat yang damai dan saling memahami antar sesama sehingga sejalan dengan semboyan negara kita yaitu Bhineka Tunggal Ika berbeda-beda tetapi tetap satu.

2. Qana'ah

Sifat qana'ah adalah sifat yang ikhlas yaitu ikhlas dalam menerima dan selalu bersyukur atas segala apa yang berada disekitar kita karena yakin bahwa segala yang terjadi adalah atas kehendak Allah. Singkatnya dengan

\footnotetext{
${ }^{10}$ Muhammad Anas Ma`arif, 'Pendidikan Multikultural Sebagai Pembentukan Karakter Peserta Didik', TA 'LIM : Jurnal Studi Pendidikan Islam 2, no. 2 (15 July 2019): 1-17.
} 
memiliki sifat qana'ah kita akan selalu bersyukur dengan apa yang telah menjadi ketetapan Allah.

Sifat qana'ah adalah sifat dimana kita ikhlas menerima segala apa yang ada disekitar kita atau apa yang kita miliki namun dalam hail bukan berarti kita menerima segala segalanya tanpa ikhtiar tentunya dalam hal ini kita sebagai seorang pendidik tentunya harus mampu memahamkan peserta didik tentang sifat qana'ah yang sebenarnya. Sifat qana'ah tentunya sangat penting untuk di tanamkan kepada diri pesera didik khusunya dalam menyikapi lingkungan sekitarnya yang sekirahnya peserta didik tersebut berada dilingkungan yang berbasis multikultural sehingga dengan sifat qana'ah ini peserta didik akan bisa menerima lingkungan sekitarnya sehingga dalam bersosial tidak membuat perserta didik menjadi kaku dan kurang baik dalam bersosial.

Untuk itu perlunya sifat qana'ah ini umtuk diajarkan kepada peserta didik khusunya dalam pemdidikan agama Islam disekolah. Disekolah yang berbasis madrasah tentunya hal ini dapat diajarkan kepada peserta didik melalui pelajaran Akidah Akhlak yang menjadi salah-satu mata pelajaran di sekolah yang berbasis madrasah hal ini tentunya secara real sudah dapat dipastikan bahwa peserta didik yang sekolah di madrasah sudah dipastikan telah mendapatkan pembelajaran tentang hal ini melalui pembelajaran yang mereka da

patkan dimadrasah walaupun sebenarnya dalam praktiknya belom menjanjikan. Tetapi beda halnya dengan sekolah yang tidak berbasis madrasah pelajaran agama menjadi satu kesatuan dalam satu mata pembelajaran yang pastinya ini tantangan bagi seorang pendidik untuk dapat mewujudkan pembelajaran agama yang memadai dan maksimal oleh karena itu seorang pendidik harus pintar dan kreatif dalam hal memilih cara mengajar yang baik sehingga nantinya pembelajaran sesuai dan tepat sesaui dengan yang ingin di capai dan menjadi bermakna karena pembelajaran yang baik tentunya harus didukung oleh sistim yang baik dan tentunya seorang pendidik yang profesional sehingga akan mampu mewujudkan suatu pembelajaran yang maksimal dan dengan pembelajaran maksimal akan menghantarkan kepada tujuan utama yaitun mampu membuat peserta didik paham dan dapat mengaplikasikan pembelajaran 
tersebut dalam kehidupan mereka sehari-hari sehingga apa yang diajarkan akan lebih bermakna.

Hal ini sangatlah berpotensi besar untuk bisa mewujudkan pembelajaaran salah-satunya dapat mewujudkan pembelajaran multikultural yang baik karna berhasil pembelajaran dan pembelajaran tetap sesaui sasaran yaitu materi yang diajarkan maksimal.

3. Husnuzan

Hunuzan adalah salah-satu sifat terpuji yaitu sifat dimana selalu berprasangka baik terhadap sesama sehingga membuat orang yang memiliki sifat ini selalu berkata baik dan berbuat hal yang bermanfaat.

Dalam Islam sifat ini sangatlah diajurkan dan Islam adalah tempat dari semua akhlak terpuji, baik kepada Allah, kepada sesama, dan kepada semua makhluk adsa di bumi ini. Sifat husnuzan ini tentunya sangat penting apalagi dalam bermsyarakat tentunya hal ini perlu agar ketika sifat ini pada diri peserta didik maka peseta didik akan saling menhormati antar sesama dan tidak saling berburuk sangka terhadap apa yang dia liat dalam masyarakat sehingga nantinya tidak akan menimbulkan salah paham.

Apa terlebih peserta didik yang hidup di tengah masyarakat yang multikutural hal ini perlu ada pada diri peserta didik agar peserta didik tidak mudah menyalahkan suatu kelompok tertentu tanpa dia memahami akan kondisi dan situasi yang dia sedang hadapi oleh karena itu perlunya penanaman sifat husnuzan kepada peserta didik dengan mengarjakn dan menanamkan nilai-nilai huznuzan dalam pembelajaran contohnya dengan memberikan pengertian kepada mereka dengan baik tentang arti perbedaan dan pemahaman kepada peserta didik tentang arti dari perbedaan dengan pahamnya mereka tentang hgal tersebut maka akan mendorong mereka untuk dapat berprasangka baik terhapap lingkungan mereka dan akan bisa menghormati serta menghargai adanya perbedaan yang terjadi dilingkungan mereka. ${ }^{11}$ Oleh karna itu penting bagi seorang pendidik untuk mampu mewujudkan nilai tersebut bagi peserta didik. Dengan begitu akan mampumenciptakan nantinya suasana yang nyaman bagi lingkunagan masyarakat khusunya lingkungan peserta didik itu tersebut.

\footnotetext{
${ }^{11}$ Mustopa, 'Akhlak Mulia Dalam Pandangan Masyarakat', 271.
} 


\section{Suka menolong}

Suka Ta'awun adalah sifat saling membantu atau menolong satu sama lain. Manusia adalah makhluk sosial yang pastinya kalau dikatakan makhluk sosial berarti makluk yang hidup berdampingan dan saling membutuhkan sebab pada dasarnya manusia tidak bisa hidup sendirian melainkan membutuhkan satu-sama lain untuk menjalankan kehidupan. Dalam masyakat kita sering melihat beberapa kegiatan sosial yang menggambarkan akan pentingnya hidup bersosial atau kebersamaan seperti kegiatan gotong royong, kerja bakti, jum'at bersih, dan masi banyak lagi kegiatan-kegiatan lainnya yang dapat kita lihat dalam kehidupan sehari-hari. Dengan saling membantu antar sesama maka akan banyak hal yang bisa kita lakukan dalam hal yang bermanfaat pastinya sebab salah-satu agar terwujudnya perubahan dan kemajuan bangsa ini terletak pada bagaimana persatuan dan kesatuan kita serta kebersamaan dengan semangat juang yang tinggi yang merata untuk membangun negeri kita yang tercinta ini.

Maka dari itu pentingnya sifat ini untuk diajarakan kepada peserta didik sehingga peserta didik nantinya akan memiliki sifat mau membantu sesamanya salah-satunya mau menjaga kerukuran yang ada dilingkungan sehingga tidak terjadi salah paham atau hal yang tidak dinginkan. Sifat ini juga bisa membuat peserta didik menjadi baik dan pengertian serta mau memahami orang lain dan tidak egois atau mau menang sendiri dan tidak menghargai orang lain yang ada dilingkungan sekitarnya. Dengan peserta didik memiliki sifat seperti ini maka akan baik bagi dirinya dan lingkungan sekitarnya karna akan membentuk dirinya menjadi pribadi yang baik serta berjiwa sosial yang baik dan peduli terhadap sesama sehingga nantinya akan tercipta lingkungan yang baik dan damai jauh dari perpecahan dan perselisihan. Ini perlu dibiasakan kepada peserta didik agar mempunyai sifar ini sebab dengan sifat ini akan memudhakan peserta didik dalam bermasyarakat khusunya dalam lingkungan yang berbasis multikultural.

5. Berkata baik atau menjaga lisan

Menjaga lisan Khifdul adalah suatu sikap yang selalu berkata baik atau selalu mengucapkan kata-kata yang baik serta menjaga dari perkataan 
yang tidak baik dan kotor. Menjaga kata-kata atau ucapan sangatlah penting sebab ucapan sangatlah berbahaya jika tidak dijaga dengan baik dan berpotensi besar merusak ikatan persaudaraan dan juga persahabatan serta mengundang perselisihan dan pertikaian diantara sesama manusia. banyak sekali contoh pertikaian dan perselisihan yang timbul akibat perkattaan dan lisan dari orang-orang yang tidak bisa menjaga perkataan atau lisannya dengan baik sehingga mengeluarkan kata-kata yang tidak pantas, mengeluarkan kata-kata yang menyakitkan hati orang lain, memfinah, mengaduh dombah dan masih banyak lagi hal-hal buruk yang dapat ditimbulkan melalui lisan atau perkataan yang tidak bisa dijaga sehingga menimbulkan perpecahan yang dapat merusak kesatuan, lebih parahnya lagi akibat hal tersebut menjadikan lingkungan masyarakat kurang harmonis dan baik sehingga sangat berdampak besar bagi kelangsungan bangsa ini

oleh karna itu pentinnya sifat ini dinamkan kepada peserta didik agar peserta didik bisa menjaga perkataannya sehingga tidak membuat orang lain tersinggung dan sakit hati hingga menimbulkan perselisihan dan perpecahan dilingkungan peserta didik tersebut. Hal ini perlu diperhatikan apalagi seorang peserta didik yang hidup di lingkungan yang berbasis multikultural hal ini tentunya sangat perlu diterapkan sebab nantinya akan menimbulkan masalah yang tidak diinginkan. Oleh karena itu jika sifat ini dimiliki oleh peserta didik maka peserta didik akan bisa menciptakan suanasana yang baik melalui komunikasi serta perkataan yang baik yang mampu membuat suasana menjadi baik dan jauh perselisian apalagi sampe memicu kerusahan. Sebab peserta didik adalah generasi mudah penerus bangsa yang harus dicetak dengan baik melalui pendidikan yang maksimal agar nantinya mereka mampu menjaga kerukunan bangsa ini dengan tetap mempertahankan nilai-nilai budaya yang telah ada supaya tetap kokoh dan menjadi pemersatu di seluruh kalangan yang ada agar terciptanya suasana kerukunan bangsa sesuai dengan yang diharapkan oleh bangsa dan yang diajarkan oleh Agama.

6. Menghormati orang lain

Menghormati orang lain atau Ta'dim yaitu sifat mau menghormati orang lain. Dalam bersosial dalam masyarakat tentunya ada banyak sekali 
aturan dan adab yang harus diperhatikan salah-satunya dengan menghargai orang lain atau menghormati orang lain yang ada lingkungan kita, karena pada dasarnya setiap orang mau mendapatkan perlakuan yang baik dari orang lain dalam hal ini tentunya ingin dihargai atau dihormati oleh orang lain. Negara kita ini adalah negara yang kaya akan budaya dab etnik daerah memiliki budaya yang berbeda dan dari budaya tersebut pastinya akan membentuk karakter mereka, dalam hal tentunya penting bagu setiap peserta didik untuk mengetahuinya sehingga nantinya ketika mereka melihat satu perbedaan disekitar mereka mereka akan paham tentang hal tersebut sehingga dengan pemahaman mereka nantinya akan membuat mereka menghargai perbedaan tersebut. Karna sering kali kita melihat dilingkungan masyarakat akibat kurang tau kita terhadap suatu budaya tertentu yang apada akhirnya akan membuat kita mudah menyalahkan dan cenderung risih dengan hal tersebut kalau sudah seperti takutnya nanti akan terjadi pergeseran nilai yang nantinya akan terjadi dilingkungan masyarakat.

Untuk itu Sikap ini perlu ada pada peserta didik pastinya sebab ketika peserta didik hidup dilingkungannya kemudian menjadi pribadi yang egois dan tidak mau menghargai dan menghormati orang lain maka akan memicu banyak hal yang tidak dinginkan serta konflik di antara sesamanya yang akan terjadi dilingkungan. Oleh karena itu penanaman sifat ini perlu kepada peserta didik melalui pembelajaran sehingga nantinya peserta didik akan mampu dan mau menghargai dan menghormati orang lain khusnya perbedaan yang ada dilingkungan sekitarnya. ${ }^{12}$

7. Tawadhu' ( sopan dan satun )

Tawadhu' adalah sikap sopan dan santun dimana orang yang memiliki sifat ini adalah orang yang ramah dan baik tutur kata serta perbutannya kepada orang lain. Sikap sopan dan santun ini merupakan sikap yang baik dan perlu dimiliki oleh peserta didik. peserta didik yang memiliki sifat ini akan bagus dalam bersosial dan disenangi oleh lingkungannya sebab pada dasarnya orang atau masyarakat memang menyukai orang-orang yang sopan serta peserta didik yang memilki sifat seperti ini tidak akan

${ }^{12}$ Syarifah Habibah, 'Akhlak Dan Etika Dalam Islam', Jurnal Pesona Dasar 1, no. 4 (2015): 75. 
mengangap remeh orang lain. Sikap tawadhu' juga sangat dianjurkan di ajarakan dalam agama Islam sebab dengan sifat tawadhu' juga akan menjadikan kita semakin bersyukur dengan apa yang kita miliki dan menghargai apa yang orang lain miliki.

Dalam pembelajaran perlunya kita sebagai pendidik untuk menanamkan hal ini. Dimulai dari bagaimana mereka bisa sopan dan santun kepada gurunya dengan mengajarkan nilai-nilai dan membiasakannya seperti tidak membanta, tidak melawan guru dan tidak pula berkata kasar. Bila hal ini sudah tertanam dalam perilaku peserta didik maka ketika dia berada dilingkungan sekitarnya dia akan bersikap seperti yang semestinya yaitu menghargai orang lain apalagi orang yang lebih tua, seperti orang tua, saudaranya serta masyarakat yang hidup di lingukungannnya.

8. Memirkan kepentingan bersama

Memikirkan kepentingan bersama atau I'tisar adalah suatu sifat dimana lebih memikirkan kepentingan bersama dari pada kepentingan diri sendiri untuk mendapatkan kepentingan sesama demi terwujudnya keadilan. ${ }^{13}$ Sekarang ini banyak sekali kita lihat suatu fenomena dimana banyak sekali orang yang bertindak seenaknya, melakukan segala apa yang dia inginkan tanpa memperhatikan pihak-pihak yang nantinya akan mengalami kerugian akibnat dari perbuatan mereka tersebut. Banyak sekali contoh kasus seperti ini misalnya korupsi dengan mengambil uang orang banyak demi kepentingannya sendiri sehingga merugikan orang lain, menyenbarkan narkoba yang dapat merusak masa depan bangsa serta banyak lagi hal-hal lain yang tidak dinginkan terjadi akibat keegoisan dari mereka oleh karna itu kita perlu memperhatikan pendidikan yang baik sehingga akan menciptakan generasi-gerasi penerus bangsa yang beriman, cinta akan bangsanya menghargai perbedaan dan menjaga budaya bangsa. Maka dari itu sebagai seorang pendidik tentunya kita harus mampu menanamkan sifar I'tisar bagi peserta didik yaitu dengan mengajarkan nilai-nilai saling menyayangi dan mengasihi satu sama lain sehingga akan memunculkan sikap kepedulian terhadap sesama manusia agar

${ }^{13}$ Nurul Zuriah, Pendidikan Moral Dan Budi Pekerti Dalam Perspektif Perubahan, III (Jakarta: PT. Bumi Aksara, 2011), 8-9. 
mendatangkan generasi yang gotong royong dan saling membantu menuju perubahan yang lebih baiks

Perlunya sifat ini ada pada peserta didik sebab dengan sifat ini peserta didik tidak akan egois dan akan lebih mengutamakan kemaslahatan bersama demi terwujudnya keadilan serta jauh dari perselisihan. ${ }^{14}$ Oleh sebab itu tentunya perlu kiranya hal ini diajarkan kepada peserta didik tentang nilai-nilai kesatuan dan kebersamaan sehingga peserta didik akan menjaga kerukunan bersama demi kepentingan bersama dengan menjaga segala apa yang ada dilingkungannya seperti budaya yang ada dilingkungnya sehingga nantinya budaya yang ada akan menjadi alat pemersatu bukan pemecah belah.

9. Sifat berhati-hati

Sifat behati-hati atau wira'i adalah sifat dimana dapat menjadikan seseorang penuh dengan kewaspadaan atau berhati-hati dalam mengatasi atau menyikapi suatu masalah. Belakangan ini banyak sekali terjadi konflik dan berbagai problema dalam masyarakat yang semua itu terjadi sebab beberapa kekeliruan dan juga akibat orang-orang yang tidak bertanggung jawab dan suka memanfaatkan situasi. Oleh karena kita sebagai pendidik juga harus berhati-hati ketika mengajarkan sesatu kepada peserta didik gunakanlah bahasa yang santun serta berikan mereka pengertian yang baik karna terkadang akibat kurangnya perhatian kita sehingga kita tanpa sadar mengejarkan sesuatu yang mungkin peserta didik kurang memahami hinggu memicu salah paham, ini perlu menjadi perhatian bersama khususnya bagi kita seorang pendidik. Oleh sebab itu perlunya sifat wira'i ini ditanamkan kepada peserta didik sehingga nanti ketika mereka berada dalam lingkungan masyarakat mereka akan berhatihati dan tidak akan sembarangan bertindak yang dan akan berhati-hati dalam memutuskan segala sesuatu sebelum melakukannya.

Hal ini sangat baik untuk dipahamkan kepada peserta didik sehingga nantinya peserta didik juga akan berhati-hati dalam menyikapi masalah yang ada dilingkungan mereka salah-satunya adalah menyikapi perbedaan yang ada dalam masyarakat sehingga nantinya peserta didik tidak akan

${ }^{14}$ Ibrahim Bafadhol, 'Pendidikan Akhlak Dalam Perspektif Islam', Jurnal Edukasi Islami 06, no. 12 (2017): 47. 
asal bertindak yang nantinya akan menimbulkan salah paham dilingkungannya untuk itu perlunya sikap ini yang nantinya menjadi filter peserta didik dalam menyikapi masalah yang ada dilingkungannya. ${ }^{15}$

\section{c. kesimpulan}

suatu perbedaan yang ada di lingkungan kita adalah suatu hal yang wajar dan sudah menjadi hal mutlak atau Sunnatullah oleh karena itu bijaklah dalam menyikapi perbedaan. Bijak sini tentunya tak semudah yang kita bayangkan banyak sekali hal yang perlu diperhatikan dan dipahami yang tentunya itu menjadi tantangan bagi kita tentunya yang pastinya menjadi tantangan juga bagi pendidikan dimana pendidikan harus mampu menjawab hal tersebut, apalagi pendidikan agama Islam yang memang harus berperan aktif dalam hal ini. $€^{16}$ Karena pendidikan agama sangat berpengaruh terhadap lingkungan yang ada dalam masyarakat. Ini menjadi tugas pula bagi pendidik dimana seorang pendidik harus malaksanakan tugas dengan maksimal sehingga sesuai dengan apa yang diharapkan oleh pemerintah dan masyarakat sesuai dengan kebutuhan yang dibutuhkan dalam lingkungan masyarakat. Di Indonesia tentunya perbedaan bukanlah hal yang asing lagi, seperti yang tela dijelaskan diatas tadi bahwasanya Indonesia adalah negara yang beragam akan suku, etnik, agama dan budaya yang tentunya hal ini harus di jaga dan menjadi pemersatu kita dalam hidup berbangsa dan bernegara agar terciptanya kerukunan antara sesama masyarakat sehingga nantinya dapat terwujud masyarakat yang damai dan sejahtera serta bebas dari perselisihan dan pertikaian dan pastinya hal ini bila dapat terwujud maka akan sesuai dengan semoboyan negara kita yaitu Bhineka Tunggal Ika yang artinya berbeda-beda tetapi tetap satu dan sejalan dengan agama Islam yaitu agama rahmatan lil alamin. Untuk mencapai tujuan tersebut kiranya ada beberapa kiat-kiat yang perlu dilakukan dan diperhatikan. Beberapa hal tersebut adalah (1) Torensi yaitu sikap dimana ,( 2) Qana'ah, (3) Husnuzan, (4) Ta'awun, (5) khifdul, (6) Ta'dim, (7) Tawadhu', (8) I'tisar, (9) wira'i.

Beberapa hal tersebut kiranya perlu diperhatikan serta ditanamkan kepada peserta didik sebagai bekal nanti bagi mereka untuk menghadapi tentangan masa depan salah-satunya tantangan multikultural. Islam sudah mengajakan hal tersebut.

\footnotetext{
${ }^{15}$ Mustopa, 'Akhlak Mulia Dalam Pandangan Masyarakat', 271.

${ }^{16}$ Dharma Kesuma, Cepi Triatna, and Johar Permana, Pendidikan Karakter, ed. Anang Sholihin Wardan, IV (Bandung: PT. Remaja Rosdakarya, 2013), 8-9.
} 
Semua hal itu ada dalam Islam dan sangat di ajurkan sebab agama Islam agama yang sangat luas dan memperhatikan segala aspek kehidupan tanpa terkecuali karna Islam adalah agama rahmatan lil alamin yaitu rahmat agi seluruh alam. Maka dari itu sudah sepatutnya kita mengamalkan ajarannya karna ajaran Islam adalah ajaran yang sempurna yang mampu menjawab tantangan zaman disetiap zamannya.

Sebagai seorang pendidik khususnya pendidikan agama ini menjadi salah-satu tantangan kita bagaimana mampu mewujudkan hal tersebut. Sebab ini menjadi tugas kita dan bagian dari dakwah yang dianjurkan oleh agama kita harus kita laksanakan dan kita lakukan oleh sebab itu kita sebagai pendidik harus bersungguh-sungguh untuk bisa mewujudkan hal tersebut melalui pendidikan yang maksimal sehingga hasil yang diperoleh sesuai dengan apa yang diharapkan oleh tujuan agama dan pendidikan pastinya disekolah agar mampu mencetak generasi mudah yang berakhlatul karimah dan mampu tampil dan berjaya di zamannya yang tentunya sesaui dengan ajaran moral dan pendidikan yang telah diajarkan serta tidak melupakan nilainilai budaya yang baik yang ada dilingkungan sekitarnya. Dengan demikian diharapkan pendidik akan benar-benar profesional dalam hal ini sebagai wujud dari tanggung jawab atas tugas yang dipikul serta kewajiban berdakwah menebar rahmat melalui ilmu yang sangat diajurkan dalam kita yakni agama Islam agama rahmatan lil alamin. Dan dengan demikian ketika para pendidik sudah melaksanakan tugasnya dengan semaksimal mungkin serta penuh keikhlasan maka nantinya diharapkan akan mampu memahamkan peserta, didik memaksimalkan potensi peserta didik, serta menjadikan peserta didik yang berkualitas, berwawasan luas, dan bermaysrakat dengan landasan agama yang kuat serta akhlak yang terpuji.

\section{Saran}

Berdasarkan hasil penelitian kualitatif dengan menggunakan metode Library Reseach maka segala apa yang berhubungan dengan isi pada ini terdapat beberapa saran atau masukan mengenai tulisan ini supaya nanti dapat meningkatkan lagi penelitian yang nantinya akan dilaksanakan selanjutnya :

1. Sebaiknya jika untuk penelitian dengan mennggunakan penelitian kualitatif yaitu dengan melalui Library Research ini maka akan lebi baik bila penulis harus memahami dulu judul yang akan digunakan nantinya, sehingga nanti akan lebih mengerti dan akan lebih memahami tentang bagaimana materi yang nantinya akan di teliti oleh peneliti. 
2. Untuk peneliti selajutnya di harapkan tidak hanya menggunakan penelitian Library Research saja, tetapi dengan menggunakan sebuah penelitian yaitu dengan melakukan observasi atau terjun langsung melihat kondisi dilapangan itu seperti apa untuk nantinya dijadikan dasar dalam penelitian

3. Untuk peneliti selajutnya supaya nantinya akan lebih mehami lagi materi yang akan di teliti sehingga nantinya akan memunculkan inovasi-inovasi pembelajaran agar terciptanya bagaimana pembelajaran yang baik bisa nantinya diterapkan sehingga akan menghasilkan pembelajaran yang maksimal.

\section{DAFTAR PUSTAKA}

Bafadhol, Ibrahim. 'Pendidikan Akhlak Dalam Perspektif Islam'. Jurnal Edukasi Islami 06, no. 12 (2017).

Habibah, Syarifah. 'Akhlak Dan Etika Dalam Islam'. Jurnal Pesona Dasar 1, no. 4 (2015). Kesuma, Dharma, Cepi Triatna, and Johar Permana. Pendidikan Karakter. Edited by Anang Sholihin Wardan. IV. Bandung: PT. Remaja Rosdakarya, 2013.

Ma`arif, Muhammad Anas. 'Internalisasi Nilai Multikulutural Dalam Mengembangkan Sikap Toleransi ( Studi Di Di Pesantren Mahasiswa Universitas Islam Malang)'. Nazhruna: Jurnal Pendidikan Islam 2, no. 1 (24 March 2019). https://doi.org/10.31538/nzh.v2i1.179.

__. 'Pendidikan Islam Dan Tantangan Modernitas'. Nidhomul Haq: Jurnal Manajemen Pendidikan Islam 1, no. 2 (26 March 2016): 47-58.

—. 'Pendidikan Multikultural Sebagai Pembentukan Karakter Peserta Didik'. TA 'LIM : Jurnal Studi Pendidikan Islam 2, no. 2 (15 July 2019): 1-17.

Mahfud, Choirul. Pendidikan Multikultural. VI. Yogyakarta: Pustaka Pelajar, 2013.

Mustopa. 'Akhlak Mulia Dalam Pandangan Masyarakat'. Nadwa 8, no. 2 (2014).

Rohani. 'Wawasan Multikultural Dalam Pendidikan Agama Islam'. JUrnal Al-Qalam XI, no. 63 (2000): 62-63.

Suparlan, Parsudi. 'Menuju Masyarakat Indonesia Yang Multikultural'. Antropologi Indonesia 69 (2002): 91-100.

Yahya, Muhammad. 'Pendidikan Islam Pluralis Dan Multikultural'. Lentera Pendidikan 13, no. 2 (2010): 175-91. https://doi.org/10.1016/0165-7836(95)00430-0.

Zuriah, Nurul. Pendidikan Moral Dan Budi Pekerti Dalam Perspektif Perubahan. III. Jakarta: PT. Bumi Aksara, 2011. 
